\title{
Enabling an effective knowledge and information flow between the phases of building construction and facilities management
}

\author{
Adeline Zhu Teng Tan \\ Celtic Builders, Perth, Australia, and \\ Atiq Zaman, Monty Sutrisna \\ School of Design and the Built Environment, Curtin University, Perth, Australia
}

\begin{abstract}
Purpose

The purpose of this study is to investigate ways of transferring knowledge and information during the life cycle phases of construction projects, particularly between the construction and occupancy phases, and to find an approach to minimize knowledge and information gaps during handover process.
\end{abstract}

Design/methodology/approach

The study applied a qualitative approach involving a literature review and archival analysis of information flow in the studied cases of construction project, followed by a cross-cases analysis and expert interviews. Data on information flow was collected from three cases of building construction projects in Perth, Western Australia. In addition, a total of eighteen local facilities management experts were interviewed to identify the key reasons of knowledge and information gaps and to propose an effective knowledge flow model.

Findings

The findings of this study indicated a significant knowledge and information gaps exists during the handover process in construction projects in Western Australia. The findings of case analysis and expert interviews identified that project handover guidelines were often ignored in construction projects in Western Australia and the handover phase was not given the same priority as the design and construction phases by most of the project stakeholders, which led to information and knowledge gaps between the project construction and post-occupancy phases.. The study conducted integrated knowledge and information flow modelling to analyse the knowledge and information gaps followed by mapping the gaps against existing knowledge sharing frameworks before proposing an integrated knowledge sharing conceptual model to improve current practice and to enhance the information flow during various phases of the construction project life cycle.

Research limitations/implications

The study is based on three cases in Perth, Western Australia and thus the findings and recommendations are contextual. Whilst laying a good foundation to do so, a further research is needed to investigate more cases in Western Australia and beyond to fully generalise the findings from this study.

Originality/value

The study contributes to improve handover process and information flows in project life cycle phases in Western Australia and develop an information flow model followed by bringing together existing 
knowledge sharing frameworks (KSFs), namely the Open Communication Channel (OCC), Soft Landing Framework (SLF) and Building Information Modelling (BIM) to propose an integrated knowledge sharing conceptual model. The methodology used here to analyse the information flow in a diagrammatic manner, the mapping of FM issues against the KSFs capabilities and a conceptual model to facilitate change in the industry's silo mind-set are the main contributions of this paper.

Keywords: information flow, project handover, operations and maintenance, data gap, facility management

\section{Paper type: Research paper}

\section{Introduction}

Facilities Management (FM) requires multidisciplinary activities with extensive information about buildings (Becerik-Gerber, et. al., 2011). Building operators and facilities managers perform their functions based on data and information received from various teams of building contractors, consultants, subcontractors and suppliers. However, inadequate data interoperability exists because of the highly fragmented nature of the built environment industry, and inconsistency in technology adoption among project stakeholders (Gallaher et al., 2004).

A poor documentation and inadequate data interoperability have contributed to the overall poor performance of the built environment industry in Australia, which is evident with the significant increase of adversarial behaviour among project stakeholders (Engineers Australia, 2005). This is attributable to the traditional working environment in which project stakeholders work in "silos" and "over the wall" (Anumba et al., 2002). This has resulted in a substantial loss in the value of data when handed over to the FM teams because they are the final recipients of this value-depreciating data (Eastman et al., 2011, p.153). Since, O\&M phase represents the longest period and incurs the highest lifecycle costs (Lee and Akin, 2010), it is therefore important to investigate the information flow between the "silos" in particular between design and construction and O\&M, to facilitate more effective and efficient O\&M (Collinge et al., 2009).

The onus is on the facilities managers to operate and maintain the buildings within tight budget constraints, on top of achieving building owners and occupants' satisfaction and expectations, maintaining the normal operation of buildings, and complying with relevant building codes and regulations especially in terms of occupational health and safety (Flores-Colen et al., 2010). In order to carry out the aforementioned functions effectively, adequate information on the building fabric, systems and fittings is essential as effective O\&M is driven by information as evidenced by Su et al. (2011).

A number of studies have identified that the risk of a knowledge loss at a project's end is a serious problem for organisations, especially in knowledge-intensive industries such as facilities management, healthcare facilities and corporate companies (Pothier et al., 2005; Loebbecke et al., 2016). Consequently, there is a need to improve the effectiveness and efficiency of the ongoing O\&M through the improvement of information flow between design and construction phase and the O\&M phase. By thoroughly understanding and identifying the information gap between these phases, potential solutions can be suggested to mitigate the information gap. In recent years various knowledge and information sharing platforms such as open communication channels, soft landings framework and building information modelling, and others have emerged as potential ways to effectively minimise 
knowledge gaps by sharing information, providing feedback, learning from the past and projecting future risks (Motawa and Almarshad, 2013; Way and Bordass, 2005).

The aim of this study is to enhance the effectiveness of information and knowledge flow between building handover and the O\&M of office buildings projects. In order to satisfy the aim, the following objectives are investigated, (i) current practice of building handover and O\&M; (ii) develop a process map depicting the information flow in O\&M phase, and (iii) identify factors contributing to the information flow and formulate recommendations to improve the information handover for O\&M.

\section{Information flow in project life cycle phases}

Generally various data information flows among major project phases, i.e. project planning, design, construction, operation and decommission. Effective information flows among project teams during different life cycle phases is very important in implementing quality assurance (Zeng et al., 2007).

In practice, the first three phases are given more priority as these phases are interlinked and executed in a collaborative environment. The operation and decommission phases, however, are mostly operated separately and independently. Therefore, there is a risk of lack of data sharing during the handover process.

\section{Information flow during project handover}

During handover, project data are transferred from the design and construction teams to the FM teams. The data in the handover package vary from project to project, but will generally include constructed drawings and schedules, product data sheet and manufacturer pamphlets, asbestos material assessments, hazardous material reports, fire performance and containments details, actual versus planned project costs and schedule, operation and maintenance (O\&M) manuals, product warranty information, and spare parts lists (UTAS, 2011). All the information required to be handed over to the building owners and operators should be clearly stipulated in the building contracts and sub-contracts to avoid any confusion and inconvenience to the project stakeholders (Fallon and Palmer, 2006). The handed over data need to have an adequate interoperability between projects stakeholders to avoid significant increase the anticipated O\&M costs. This particular problem have been report to cost as high as US $\$ 15.8$ billion to the US capital facilities for instance (Gallaher et al., 2004).

\section{Information requirements in operation and maintenance}

The information required in the operation and maintenance (O\&M) phase includes legal, financial and physical aspects of the facilities - legal information such as zoning, building codes, and fire and safety regulations, financial information such as lease and operating revenues, and physical information such as equipment and systems operating parameters, inspection and maintenance schedules, and details of warranties (Fallon and Palmer, 2006). It is essential that pre-project handover meeting be organised prior to the proposed project practical completion to discuss and agree on the handover process, requirements and outcomes (East et al., 2013).

Based on the data, the FM teams will generate FM databases which contain information regarding the operation and maintenance of building elements and services, plant and equipment, fittings and furniture (DTF, 2005). From there, initial short term (up to three years) and long term (up to seven years) preventive maintenance plans and regimes are formulated for each building component requiring maintenance (DTF, 2005). 
Table 1: The key information required during the handover phase (adopted from Aoalsteinsson, 2014; Fallon and Palmer, 2006)

\begin{tabular}{|c|c|c|}
\hline Phases & $\begin{array}{l}\text { Stakeholders/ } \\
\text { Professionals }\end{array}$ & Required Information \\
\hline Planning & $\begin{array}{l}\text { Planners, owners, } \\
\text { developers }\end{array}$ & $\begin{array}{l}\text { - Planning documents } \\
\text { - Permit and approval documents }\end{array}$ \\
\hline \multirow[t]{2}{*}{ Design } & Architect & $\begin{array}{l}\text { - Information on building energy performance } \\
\text { - Spatial information } \\
\text { - } \quad \text { Building zoning information: fire and access information }\end{array}$ \\
\hline & Engineers & $\begin{array}{l}\text { - Spatial information: energy analysis, requirements of } \\
\text { mechanical, electrical and plumbing (MEP) components } \\
\text { - Building systems, zoning information } \\
\text { - Structural information }\end{array}$ \\
\hline \multirow[t]{3}{*}{ Construction } & Contractors & $\begin{array}{l}\text { - As-built drawings and specifications } \\
\text { - Product information: materials, manufacturers, } \\
\text { installation dates, warranties, spare parts lists, suppliers } \\
\text { and manufacturer's recommendations } \\
\text { - Certification of compliance and occupancy permit } \\
\text { - Legal information: zoning, Building Code of Australia } \\
\text { and other relevant building regulations }\end{array}$ \\
\hline & Architect & $\begin{array}{l}\text { - As-built design drawings and schedules } \\
\text { - } \quad \text { Fittings schedules }\end{array}$ \\
\hline & Engineers & - As-built MEP system drawings and schedules \\
\hline $\begin{array}{l}\text { Operation } \\
\text { and } \\
\text { maintenance }\end{array}$ & Facilities Managers & $\begin{array}{l}\text { - Condition audit and appraisal reports } \\
\text { - Occupancy information: occupancy levels, operating } \\
\text { costs } \\
\text { - Maintenance information: work orders, service reports, } \\
\text { maintenance schedules and plans }\end{array}$ \\
\hline
\end{tabular}

The O\&M phase represents the longest period of most facilities' lifecycle, and the cost incurred in this phase is higher-more than $85 \%$ of the whole-lifecycle costs (Teicholz, 2001 cited in Lee and Akin, 2010) is expended in the O\&M phase. The operations and maintenance (O\&M) phase begins after the commissioning and handover of a facility and the activities performed in the O\&M phase would vary in different type of facilities but will typically include repairs and maintenance, post-occupancy evaluation, retrofit, and final disposal or decommissioning (Sinclair, 2013).

\section{Existing information and knowledge sharing frameworks (KSFs)}

Facilities management (FM) is a knowledge-intensive discipline where the knowledge of facilities manager is exploited to ensure proper operations and maintenance (O\&M) of the facilities under their management (Pathirage et al., 2008). Therefore, concepts and frameworks leading to knowledge sharing (termed as KSF in this paper) are very important in facilities management. The KSFs can be classified as either prescriptive, descriptive, or a combination of the two (Rubenstein-Montano, et al., 2001). The knowledge management systems can be different depending upon the characteristics and typology. The KSFs attempt to address one or more of the following factors, acquire knowledge, transform information to knowledge, organise, share, evaluate, transfer and developed new knowledge-based services (Hahn, et al., 2000; Rubenstein-Montano, et al., 2001).

The use of the computer-aided facility management (CAFM) system began during space exploration (Teicholz, 2001). The CAFM data-base requires multi-stakeholder involvement and depending on the type of buildings. It often incorporates various information and design tools such as building management system (BMS), computer-aided design (CAD), computer-aided information (CIS), 
integrated workplace management system (IWMS), enterprise asset management (EAM), computerised maintenance management system (CMMS) and so on to provide effective services (Sabol, 2008; Elmualim and Pelumi-Johnson, 2009). All these tools have certain benefits and limitations in providing accessibility of accurate data in any given time (Shen et al., 2010). In addition, these tools can be very effective (or ineffective) in addressing problems arise during the post-handover period depending on whether a tool independently solves or addresses the problem or whether it requires a combination of multiple tools.

Three major and more contemporary KSFs, namely the Open Communication Channel (OCC), Soft landings Framework (SLF) and Building Information Modelling (BIM) have been identified in this research as a basis for more effective knowledge sharing in facilities management.

It is envisaged that relationship contracting could be improve the information exchange as it promotes "mutual trusts and cooperation, open and honest communication and free sharing of information" (Australian Constructors Association, 1999, p.4). This concept of open communication should be embodied into project policies to enable knowledge sharing. In this paper, such policies are termed as the Open Communication Channel (OCC). Information is rigorously exchanged in a collaborative workplace environment in OCC and thus it is seen as effective tool to collect, store and share information among various construction phases (Huczynski and Buchanan, 2001, p. 875). Information exchange in OCC can be done in various ways via formal and informal media in both deliberate and non-deliberate approaches. However, a 'high performance' team environment is essential for an effective OCC and that could be a major challenge for the construction projects (Dainty, et al., 2007). Similar to various other organisations, the City of Melbourne applies OCC as one of many effective information sharing tools for managing multi-unit residential buildings in Melbourne (Melbourne City Council, 2012).

The soft landings framework (SLF) has been proposed by the UK Government to minimise the knowledge gap in construction projects. The SLF involves various project teams during the design and construction process to ensure an effective post-construction facilities management (BIM Task Group, 2013; Usable Buildings Trust, 2014). The SLF includes 5 key stages such as inception and briefing, design development and review, pre-handover, initial aftercare, and extended aftercare and post occupancy evaluation (BSRIA, 2016). Soft Landings is not just a handover protocol, but it also links between procurement process, client and occupier relationships and longer term monitoring system (Way and Bordass, 2009). Soft Landings is not relying on any single course of action and leaning and but sharing feedback which is mandatory to improve building performance in the future (Way and Bordass, 2005). The post occupancy evaluation (POE) and feedback are the key source of information gathered through SLF, however, a study stated that POE can be seen as 'too academic' and 'too late' to benefit the project concerned (Bordass and Leaman, 2005).

Building Information Modelling (BIM) has been defined as a set of interacting policies, processes and technologies that can be used to manage building data in digital format throughout the building's lifecycle (Succar 2009). Thus it can be considered one of the most advanced computer aided tools to store and share information and knowledge related to every construction phase. BIM enables the inclusion of provides a platform for an information centric approach to share information on a single repository (Asen 2012). Building Information Modelling (BIM) was developed to provide improved methods of design, construction and communication in the industry. Significant costs involving printing and document shipping can be saved when using BIM (Coates et al. 2010). In the O\&M phase, BIM is deemed capable of reducing the time and effort to generate FM database by $98 \%$ with the appropriate level of details (Morton, 2011; Skripac and Hira, 2013). Unfortunately, the capabilities of BIM have not 
been fully exploited in FM as the technology is relatively new and its limited data exchange and lack of interoperability between different platforms may be a major limitation of BIM (Sabol, 2008; Olofsson et al., 2008).

In light of the on-going discussion, the identified $3 \mathrm{KSF}$ are considered as potential frameworks in closing the gaps in information flow between various stages in the building's life-cycle. They can offer a 'complete solution' as a standing alone framework, 'moderate solution' which works best when combined with at least another framework(s) or 'partial solution' when depending on another framework(s) in providing a solution to a particular problem. This study utilised the 3 identified KSFs to analyse the knowledge gaps during the handover process of 3 case studies and investigated how these $3 \mathrm{KSF}$ can address these issues.

\section{Research Methodology}

The study applies a qualitative research approach (shown in Figure 1) as the study is an exploratory one and it seeks a better understanding of knowledge and information gaps during the handover phase of a construction project. Qualitative research emphasise on exploring the experience and perceptions of respondents towards the research subject matter through ongoing contact with "real-life" industry situation (Amaratunga et al. 2002). Thus considered suitable for this research to fully understand the contextual situation that gives way to the gaps in knowledge and information during hand over. Semistructured interviews were conducted among experts in facilities management in Western Australia including project participants of the studied cases. In addition, the study analysed three different commercial office buildings as case studies.

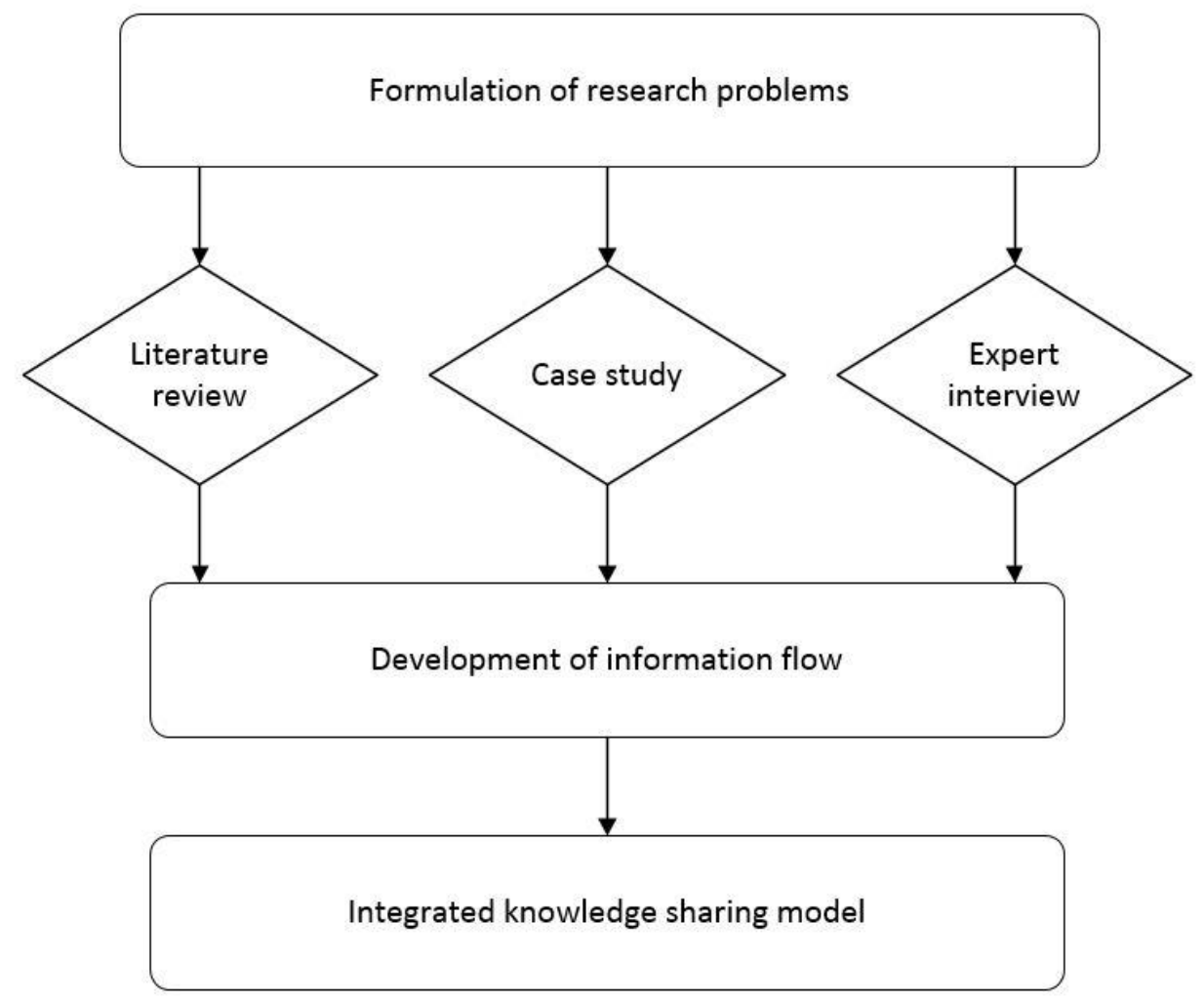

Figure 1: A simplified diagram of the research steps 
Office buildings were selected as the focus of this research due to the fact that Perth has been experiencing a boom in office buildings construction as a result of increasing demand for premium grade offices in and around the centre business district (CBD) area (PCA, 2014). This research studied 3 commercial office buildings which were completed in different years between 1997 and 2009. Even though this is not considered a longitudinal study, the selection of these cases ranging from different time of completion covers practices in the handover process over this period of time and provide insights to facilities management practices within the last 10 years. All three case study projects located in Perth CBD are commercial buildings as presented in Table 2. The case study buildings were rated differently in energy and water according to the National Australian Built Environment Rating System (NABERS). Project $B$ is listed as heritage building.

Table 2: The key features of the case study buildings

\begin{tabular}{|c|c|c|c|}
\hline Features & Project A & Project B & Project C \\
\hline Building type & Commercial Office & Commercial Office & Commercial Office \\
\hline Story & 29 & 9 & 20 \\
\hline Lettable area & $47,000 \mathrm{~m}^{2}$ & $18,000 \mathrm{~m}^{2}$ & $15,000 \mathrm{~m}^{2}$ \\
\hline Project completion date & 2003 & 2009 & 1997 \\
\hline Building use & $\begin{array}{l}\text { 24-floor levels of } \\
\text { commercial offices, a } \\
\text { mezzanine level, two- } \\
\text { levels of basement car- } \\
\text { parking facilities, two- } \\
\text { levels of plant floor } \\
\text { levels. }\end{array}$ & $\begin{array}{l}9 \text { storeys commercial } \\
\text { office space, two levels } \\
\text { of car-parking, and two } \\
\text { heritage buildings - a } \\
\text { heritage garden and a } \\
\text { restaurant. }\end{array}$ & $\begin{array}{l}17 \text { levels of } \\
\text { commercial office } \\
\text { space, two levels of } \\
\text { car-parking and a } \\
\text { recently refurbished } \\
\text { mezzanine floor } \\
\text { housing a bar and } \\
\text { restaurant, } \\
\text { gymnasium, and } \\
\text { concierge }\end{array}$ \\
\hline Energy rating & 4.5 Star & 5 Star & 4 Star \\
\hline Occupants & $\begin{array}{l}\text { A major anchor tenant, } \\
\text { and several smaller } \\
\text { tenants occupying the } \\
\text { remaining } 15 \% \text { of net } \\
\text { lettable area. }\end{array}$ & $\begin{array}{l}\text { Multi-tenants and the } \\
\text { majority tenants are } \\
\text { commercial } \\
\text { organisations including } \\
\text { an accounting firm, a } \\
\text { property group and a } \\
\text { major parking } \\
\text { management group. }\end{array}$ & $\begin{array}{l}\text { Multi-tenants } \\
\text { including } \\
\text { government } \\
\text { departments, an oil } \\
\text { and gas organisation, } \\
\text { a major property } \\
\text { group and a financial } \\
\text { advisory group. }\end{array}$ \\
\hline Heritage listed & $\mathrm{No}$ & Yes & No \\
\hline
\end{tabular}

It was considered impossible to predict the number of respondents required to achieve data saturation before interviews were conducted, however depending on the nature of the study Kvale (2007) recommended $15 \pm 10$ respondents due to the typical time and resources constraints. A total of 18 local experts in Western Australia were interviewed and 9 of them were directly involved with the three cases. It was found that data saturation [refer to Strauss and Corbin (2015) about data saturation] has been achieved for the purpose of this research. The respondents were sourced through "snowball" sampling technique where at the end of the interviews, respondents were requested to contact their colleagues who are involved in the building project and/or relevant to the study for voluntary involvement in subsequent interviews (Lewis-Beck et al., 2004). 
The interview questions were formulated based on how the questions can satisfy the research aim and objectives, and was pre-tested to eliminate ambiguity and possible misinterpretations. Open-ended questions were used in the interview to encourage respondents to provide a more detailed response, and to build rapport between the respondent and the interviewer (Richards and Morse 2007). Subsequent to the transcribing process, transcripts were submitted back to the respondents for approval. Analysis was carried out using the style of grounded theory analysis and hence resulted in theories inductively derived and developed from the study through systematic data collection and analysis (Sutrisna and Barrett, 2007), and therefore, the findings can be considered "faithful" to the research subject (Strauss and Corbin 2015, p. 24). This research only adapts the style of grounded theory methodology for its data analysis (not a full-blown grounded theory methodology) and a preliminary literature review was carried out prior to data collection with an extensive literature review carried out simultaneously with the data analysis process [please refer to Sutrisna and Setiawan (2016) for further discussion on grounded theory style of data analysis and the role of literature review]. Similar to the data analysis in the grounded theory, open, axial and selective coding were conducted to facilitate concept building and categorising findings in a structured and meaningful manner. To further ensure the reliability of the data, the interviews were conducted across three case study buildings under the management of three different organisations, as well as amongst local facilities management experts in Western Australia (WA). The use of the multiple sources of data identifies convergence and crossvalidates each other, thus help ensuring the reliability of the data (Guion, 2011).

A total of 18 experts in Western Australia $(n=18)$ from the facilities management, 9 from 3 studied projects in Perth, WA were involved in the interviews. The respondents' professional background varied as presented in table 3 . The interviews successfully attracted experts with a significant level of professional expertise. The average years of experience of the experts related to the facilities management in the construction industries were 23 year. All the 18 experts were male, which gives an indication that the facilities management sector employs more male professionals in Western Australia.

Table 3. Respondent's profiles

\begin{tabular}{lll}
\hline $\begin{array}{l}\text { Number of interviews } \\
\text { analysed }\end{array}$ & & $\mathrm{n}=18$ \\
\hline $\begin{array}{l}\text { Respondents' professional } \\
\text { background }\end{array}$ & Facilities Managers & $39 \%$ \\
\cline { 2 - 3 } & Engineering Managers & $17 \%$ \\
& Project Managers & $22 \%$ \\
\cline { 2 - 3 } & Maintenance Engineer & $17 \%$ \\
\cline { 2 - 3 } $\begin{array}{l}\text { Respondents' experience in } \\
\text { construction (in years) }\end{array}$ & BIM Managers & $6 \%$ \\
& Min & 6 \\
\cline { 2 - 3 } & Max & 36 \\
\cline { 2 - 3 } & Mean & 24 \\
\hline
\end{tabular}

To develop an understanding of the information flow between project stakeholders, the respondents were requested to share some of the defects and issues that the buildings have experienced, and their respective rectification processes as well as their insights on the knowledge and/or information that can be shared earlier to anticipate/prevent such issues during the FM phase. Through the analyses of the interviews, several themes were identified which formed the basis of the mapping of information flow in the 3 cases (see Figures 2, 3 and 4). Finally, the study proposes an optimum information flow model during various project lifecycles (in Figure 5). 


\section{Findings and Discussion}

\section{Pre-handover phase}

A series of pre-handover meetings were organised between the facilities managers and the project teams prior to practical completion in all 3 projects. It is considered important to hold these prehandover meetings because the handover outcomes will have a significant impact on the whole lifecycle of the building (respondents 2, 3, 4, 13, 15, 17 and 18). Pre-handover meetings can also improve the relevancy of handover data, which will reduce the time spent to extract the data relevant to O\&M (respondents 5, 9, 12, 16 and 18).

The main contractors and subcontractors in all 3 projects have engaged external third party specialist commissioning engineers to carry out the commissioning on their behalf. It is argued that it is not feasible to have in-house commissioning engineers because the demand for commissioning engineers fluctuates over time based on the number of current projects (respondents 3, 4, 13 and 14). As witnessed by the facilities manager, the commissioning engineers commissioned the building by comparing the commissioning data against the design data figures to detect any under-performance or malfunctioning especially for works performed to a performance specification (Prior and Szigeti, 2003). Testing and commissioning results were then compiled into a commissioning pack for the approval of the main contractor before handing over to the facilities manager. Testing and commissioning were not conducted in conjunction with the installation process of the components in all 3 projects and this has created an information gap in Project A. It was suggested that testing and commissioning should be conducted as the components are installed so that commissioning can be conducted more thoroughly thus improving the accuracy of the commissioning process (respondents 5, 12 and 13).

\section{Handover phase}

At handover, the buildings were legally handed over to the facilities manager as the building operator after the occupancy permits were obtained. The facilities managers usually involves in inspecting incomplete works, identifying defects and witnessing of commissioning (Atkin and Brooks, 2009, also supported by 12 respondents out of 18). All relevant data and documents were handed over in all projects $(\mathrm{A}, \mathrm{B}, \mathrm{C})$ to $\mathrm{FM}$ teams. In project $\mathrm{A}$, however, the as-built drawings were supplied to the facilities manager two weeks after practical completion, and as a result, construction drawings were provided to the facilities manager for reference during this interim period (respondents 3, 5, 8, 13, 14 and 17). It is essential that the main contractor and specialist subcontractors hand over these documents to the facilities manager by practical completion because it forms part of the conditions for achieving practical completion in most projects (respondents 4, 7, 14, 15 and 17). This could cause information gaps due to the provision of construction drawings that may be superseded and no longer representative. The adoption of SLF, for instance, will prevent this from happening whilst BIM would eliminate this due to the automatic provision of the most up-to-date drawings including the as-built drawings at the end of the construction works. Another example of identified issues in handover phase, in project $C$, most of the documents were handed over as hardcopy files. The CAFM was not widely applied in the 1990s. Most of the documents in Project B were handed over as digital format using the CAFM system. It is important to acknowledge that there is a significant change in the information and knowledge sharing during handover processes between projects $B$ and $C$ due to a wide application of CAFM systems. Thus, technology has become a vital part of the present asset management system.

\section{Post-handover phase}


Subsequent to practical completion and throughout defects liability period, the FM teams were also typically provided with training for the operations and maintenance of complex plant and equipment in the building. This view was opposed by some of the respondents (respondents 12, 13, 14, 16 and 18) suggesting that training should be carried out before handover. The requirements and amount of trainings were stipulated in the contracts of specialist subcontractors and manufacturers. The facilities manager has also had the opportunity for informal trainings with the specialist subcontractors and installers during defects liability period as they were contractually liable for the maintenance during the defects liability period. These hands-on trainings and demonstrations are considered paramount, and suggested to be more effective than training manuals which were provided as part of the O\&M manual during handover (respondents 3, 4, 6, 11, 13 and 15). Furthermore, outstanding and defective works were also addressed during the defects liability period which was typically 12 months. This however, can vary depending on the complexity of the building and plant installed (respondents 5, 9, 13 and 16,). Such activities during this phase would benefit from implementing the OCC approach through weekly defects meetings with the main contractor, mutually clarifying any outstanding works and defects requiring rectification by the responsible services subcontractors. Both projects $\mathrm{A}$ and $\mathrm{B}$ experienced a breakdown in information flow between subcontractors and main contractors as the information were not properly transferred through a third party (respondents 3, 6, 9, 11, 16 and 17.). As a result specific clauses were included during the initial service contracts to ensure an improve information flow between the FM team and subcontractors.

\section{Operations and maintenance phase}

The O\&M phase typically commenced after the expiry of the defects liability period, and facilities managers take ownership and responsibility of the O\&M for the building. Before the expiry of the defects liability period, in many cases there was a gradual handover of building information and maintenance responsibilities from the services subcontractors to the FM team via the main contractor. One of the main reasons was the lack of contractual obligations for services subcontractors to liaise with the FM team, and the lack of continuing interests in the building if they were not engaged in the ongoing maintenance. To improve the information transfer, services subcontractors should be contracted to the facilities managers instead of to the main contractor during defects liability period and potentially beyond (respondents 3, 4, 6, 13, 15, 16, 17 and 18). Through regular meetings (as recommended by OCC), this direct relationship between both parties will close the information gap as services subcontractors are now incentivised and contractually obliged to fully transfer the information and knowledge to the FM team throughout the defects liability period. This was found in line with the SLF to facilitate knowledge and information transfer post completion of the construction phase. During the warranty period, facilities managers should ensure that the preventive maintenance regimes developed comply with the relevant building legislations and Australian Standards especially in terms of occupational health and safety, O\&M manuals, and the manufacturer's recommendations (respondents $8,12,15,17$ and 18). The non-compliance with manufacturer's recommendations during the warranty period will void the warranty, which occurred in project $B$.

\section{Information transfer in the 3 case studies}

The issues with information flow between project stakeholders have resulted in the occurrence of several problems across the 3 studied cases. In project $B$, the facilities manager opened up a tender for the maintenance of mechanical services prior to the expiry of previous maintenance contract. However, the asset information provided to the tenderers was not up-to-date, and has not been updated since the practical completion. This was done in such a way that the tenderers were not tendering on the same basis as the previous services contractor had more knowledge of the building and its components 
compared to other tenderers (respondents 1, 6 and 8). This has significantly increased the maintenance cost because upon inspection, the winning maintenance contractor carried out the omitted works under variation order, which would certainly be priced higher than if the works was priced competitively during tender (respondents 1, 6, 14, 15 and 17). In project A, several sanitary fixtures have reached the end of their life cycle and were due for replacement, but the sourcing for replacement parts proved to be challenging because the replacement parts were no longer in the market. The faults in only several sanitary fixtures have initiated the need to replace all units in the same floor level to maintain consistency and this was found more costly than having to replace the defective units only (respondents $1,2,14,15$ and 18). If facilities managers were involved earlier in the project as they could utilise their experience in O\&M to better advise the plant and equipment selection in terms of maintainability, operating efficiency, and availability of spare parts (respondents 2, 4, 10 and 12). The lack of information provided at handover has also had a repercussion which was apparent in project $C$ as there was a leakage in the water tanks in the ceiling space. Upon inspection, it was identified that the bituminous gasket sealant between the pressed-steel panels of the water tanks dried off during the dry season thus losing its waterproofing property when water supply resumed. This occurred as the facilities manager was not provided with the information on the sealant used during handover, and with that information the defects could have been prevented from occurring (respondents 3, 4, 13 and 18). This has resulted in a cost to the building owner as the facilities manager had to rectify the defects. More details on lesson learnt are provided within the diagram of the information flows in the figures 2, 3 and 4 . 


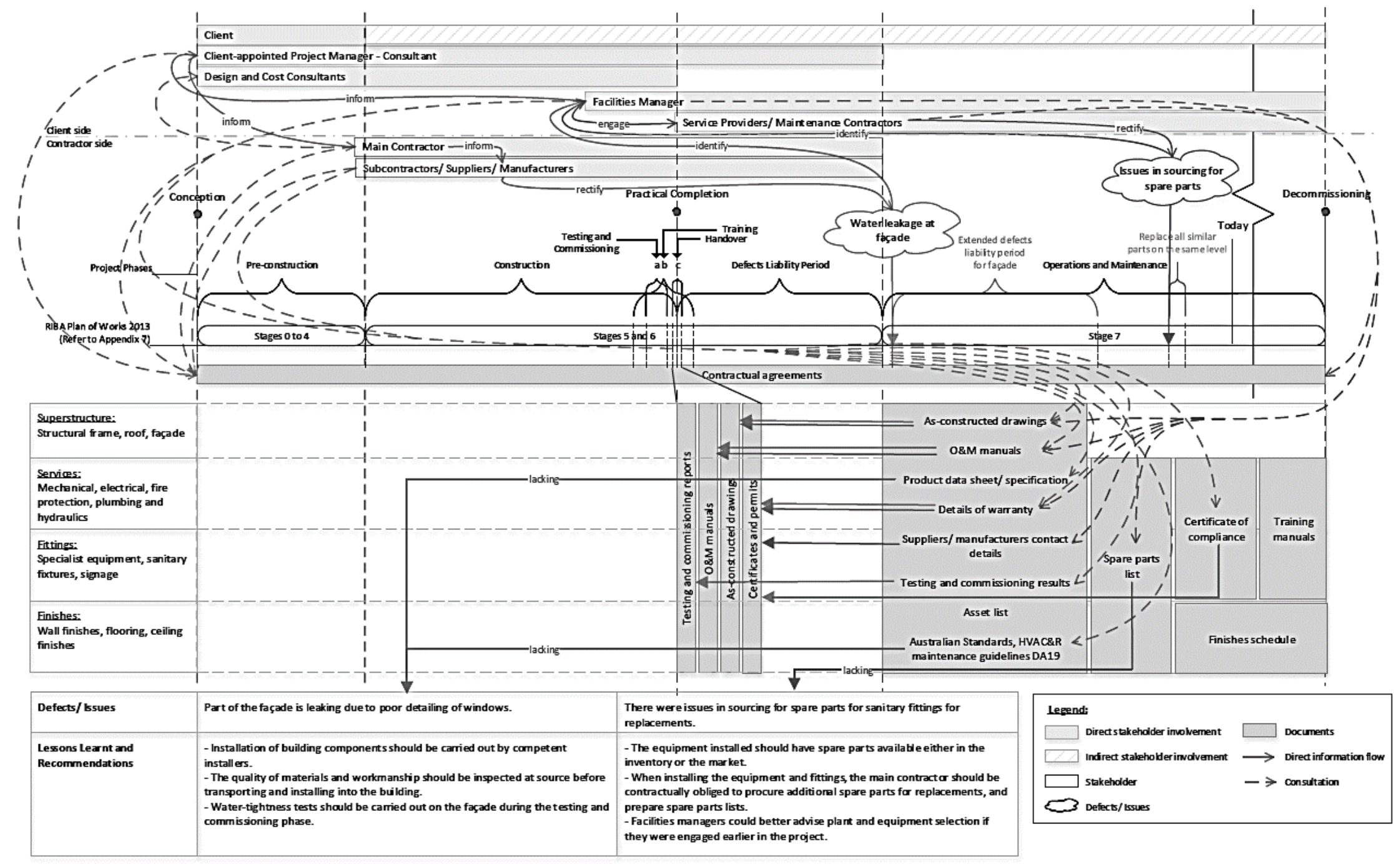

Figure 2: Information flow in project A 


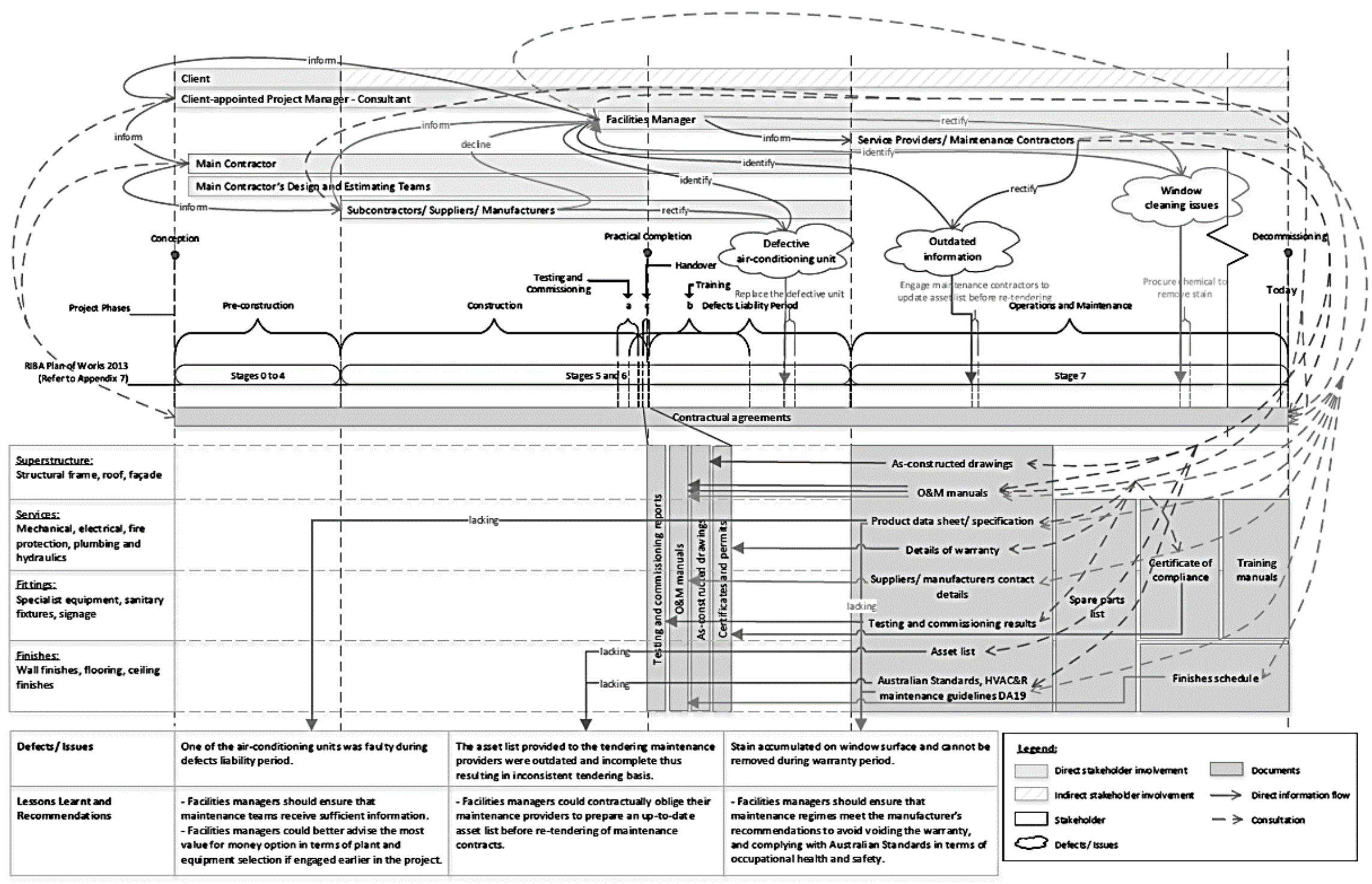

Figure 3: Information flow in project B 


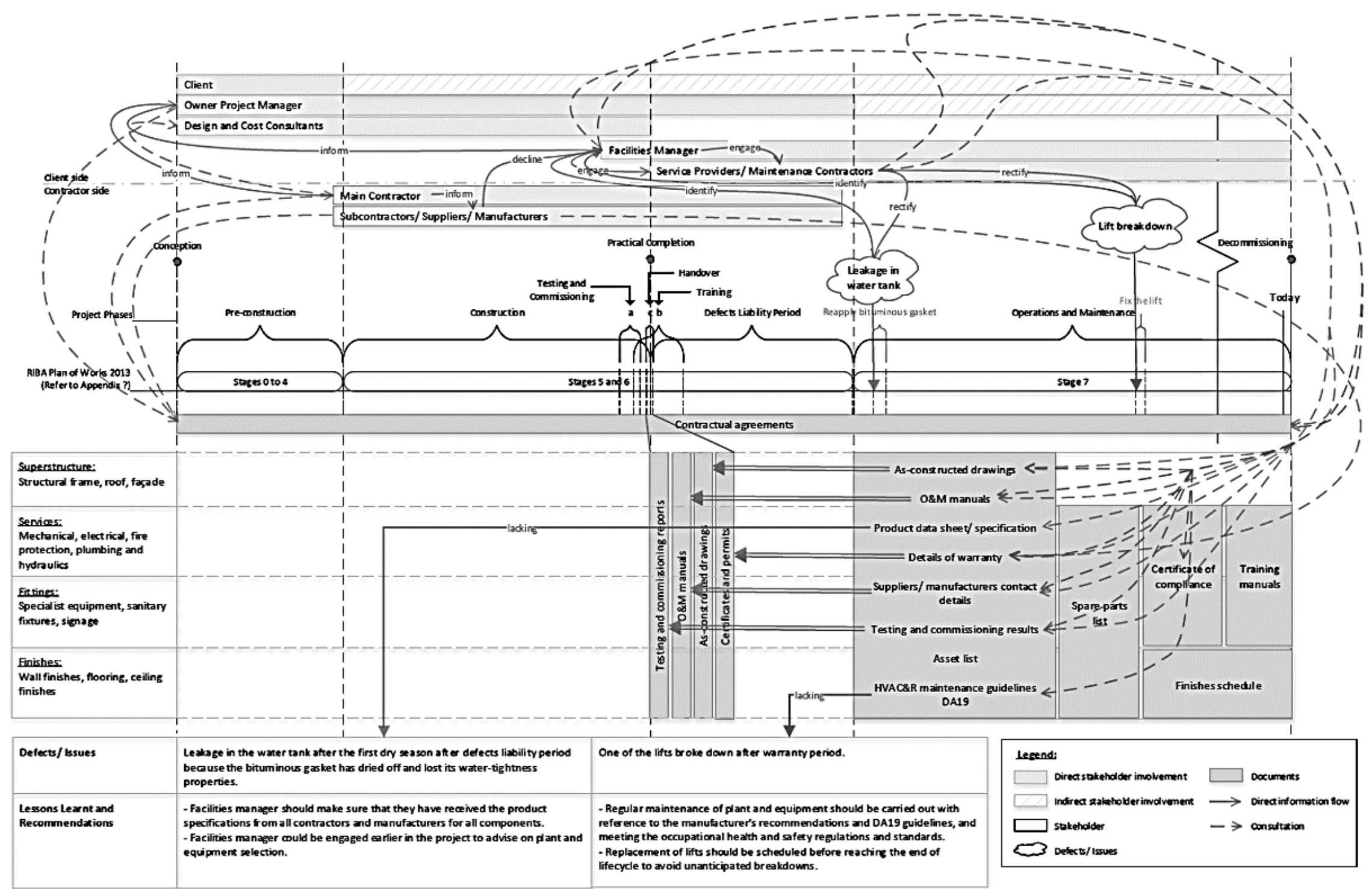

Figure 4: Information flow in project $C$ 


\section{INSERT TABLE 4}

Table 4: The Major issues faced in the studied cases due to information gap and the roles of the proposed KSFs

\begin{tabular}{|c|c|c|c|c|c|c|}
\hline \multirow[t]{2}{*}{ Major issues faced in the studied cases } & \multicolumn{3}{|c|}{ Projects } & \multirow[t]{2}{*}{ OCC } & \multirow[t]{2}{*}{ SLF } & \multirow[t]{2}{*}{ BIM } \\
\hline & A & $\mathrm{B}$ & $\mathrm{C}$ & & & \\
\hline $\begin{array}{l}\text { A standardised system was not followed } \\
\text { while collecting, sharing and storing } \\
\text { specification of equipment and product } \\
\text { data-sheets. }\end{array}$ & $\mathrm{V}$ & $\mathrm{V}$ & & $\begin{array}{l}\text { OCC guides an effective } \\
\text { communication to all relevant } \\
\text { stakeholders, but not a } \\
\text { standardisation system. }\end{array}$ & $\begin{array}{l}\text { SLF ensures a comprehensive } \\
\text { documentation of relevant } \\
\text { specification and reporting system. }\end{array}$ & $\begin{array}{l}\text { BIM allows a standardised system of } \\
\text { collecting, sharing and storing } \\
\text { specification based on the available } \\
\text { information from relevant stakeholders. }\end{array}$ \\
\hline $\begin{array}{l}\text { As-construction drawings do not match } \\
\text { with the actual structures as the designs } \\
\text { were modified. }\end{array}$ & $\mathrm{V}$ & & & $\begin{array}{l}\text { OCC provides the consultation } \\
\text { opportunities regarding updated as- } \\
\text { built drawings. }\end{array}$ & $\begin{array}{l}\text { SLF obliges to update and share } \\
\text { feedbacks among stakeholders. }\end{array}$ & $\begin{array}{l}\text { BIM provides a platform for as-built } \\
\text { drawings to be generated as the model } \\
\text { developed. }\end{array}$ \\
\hline $\begin{array}{l}\text { Relevant suppliers information not } \\
\text { available as the information were not } \\
\text { provided during project handover. }\end{array}$ & $\mathrm{V}$ & $\sqrt{ }$ & $\mathrm{V}$ & $\begin{array}{l}\text { Relevant suppliers' information are } \\
\text { shared through OCC framework and } \\
\text { stored accordingly. }\end{array}$ & $\begin{array}{l}\text { Information sharing and feedback is } \\
\text { mandatory in SLF }\end{array}$ & $\begin{array}{l}\text { Relevant suppliers information can be } \\
\text { listed and stored in the BIM model. }\end{array}$ \\
\hline $\begin{array}{l}\text { Testing and commissioning not } \\
\text { conducted as the components were } \\
\text { installed }\end{array}$ & $\mathrm{V}$ & & & $\begin{array}{l}\text { OCC prescribes involvement of } \\
\text { relevant stakeholders collaboratively } \\
\text { during the testing and commissioning } \\
\text { process. }\end{array}$ & $\begin{array}{l}\text { Testing/commissioning during the } \\
\text { handover is compulsory in SLF }\end{array}$ & $\begin{array}{l}\text { BIM provides a technological platform for } \\
\text { simultaneous testing/commissioning } \\
\text { before, during or right after installation }\end{array}$ \\
\hline $\begin{array}{l}\text { Inavailability of spare parts for } \\
\text { replacement as the item was out of date } \\
\text { and inventory was also not done }\end{array}$ & $\mathrm{V}$ & & & $\begin{array}{l}\text { OCC heavily relies on the connections } \\
\text { and collaborations with suppliers and } \\
\text { hence keeping track of parts } \\
\text { availability. }\end{array}$ & $\begin{array}{l}\text { SLF ensures inventory record as a part } \\
\text { of its protocol, which can be } \\
\text { embodied in a CAFM system. }\end{array}$ & $\begin{array}{l}\text { BIM enables the development of a } \\
\text { maintenance schedule and planning } \\
\text { including components/parts }\end{array}$ \\
\hline $\begin{array}{l}\text { Relevant O\&M manuals were not made } \\
\text { available }\end{array}$ & $\mathrm{V}$ & $\mathrm{V}$ & $\mathrm{V}$ & $\begin{array}{l}\text { OCC provides the framework for } \\
\text { sharing (including relevant O\&M } \\
\text { manuals) but not a repository. }\end{array}$ & $\begin{array}{l}\text { SLF requires the provision of relevant } \\
\text { O\&M manuals, which can be stored in } \\
\text { a CAFM system. }\end{array}$ & $\begin{array}{l}\text { BIM provides the technological platform } \\
\text { for an instant access to digital O\&M } \\
\text { manuals }\end{array}$ \\
\hline $\begin{array}{l}\text { Detecting the deadline of defect } \\
\text { liabilities }\end{array}$ & & V & & $\begin{array}{l}\text { OCC provides the framework for } \\
\text { sharing, including defect liabilities } \\
\text { deadline but not a repository. }\end{array}$ & $\begin{array}{l}\text { SLF requires the provision of relevant } \\
\text { information, which can be stored in a } \\
\text { CAFM system to ease data extraction }\end{array}$ & $\begin{array}{l}\text { BIM offers a robust repository with a } \\
\text { relatively easy access to information such } \\
\text { as the deadline of defects liabilities. }\end{array}$ \\
\hline $\begin{array}{l}\text { Provision of an up-to-date asset list was } \\
\text { not possible due to out-dated and } \\
\text { incomplete information provided by the } \\
\text { maintenance providers }\end{array}$ & & $\mathrm{V}$ & & $\begin{array}{l}\text { OCC requires continuous } \\
\text { collaboration and communications to } \\
\text { update information, including asset } \\
\text { list. }\end{array}$ & $\begin{array}{l}\text { SLF ensures a comprehensive asset } \\
\text { lists, however, a manual update } \\
\text { system requires constant updates. }\end{array}$ & $\begin{array}{l}\text { BIM ensures the continuous collection of } \\
\text { and provides a repository for the most } \\
\text { updated and complete asset list as the } \\
\text { project progress }\end{array}$ \\
\hline $\begin{array}{l}\text { Scheduled maintenance was missed and } \\
\text { the maintenance did not meet the } \\
\text { manufacturer's requirements }\end{array}$ & & V & $\mathrm{V}$ & $\begin{array}{l}\text { OCC promotes collaboration and } \\
\text { communication and developed skills } \\
\text { in guiding the manufacturer's } \\
\text { requirement }\end{array}$ & $\begin{array}{l}\text { SLF follows a strict protocol in } \\
\text { satisfying the manufacture } \\
\text { requirements during O\&M }\end{array}$ & $\begin{array}{l}\text { BIM provides the technological platform } \\
\text { to plan and control maintenance } \\
\text { schedule and manufacturers } \\
\text { requirements }\end{array}$ \\
\hline
\end{tabular}

NOTE:

Partial solution

Moderate solution

Complete solution 
Table 4 presents the summary of the key issues faced in the studied cases against the proposed KSFs, i.e. OCC, SLF and BIM to demonstrate how these issues can be addressed by the KSFs. A 'non-shaded' cell in table 3 indicates the capabilities of a particular KSF in addressing the issue as a 'partial solution' which means the KSF can partially solve or address the problem but that KSF is not sufficient to address the issue as a standing alone framework. A 'lightly-shaded' cell represents the capability of a particular KSF to provide a 'moderate solution' to the issue, i.e. sufficient in addressing the issue but optimum solutions can be generated by combining it with another KSF(s). Finally, the 'darkly-shaded' box represents the capabilities of a KSF to provide a 'complete solution', i.e. sufficient to be utilised as a standing alone framework to fully address an issue. From the analysis presented in table 4, it became apparent that BIM is capable of providing 'complete solution' to many of the identified issues. However, none of the KSFs included here can be regarded as the "silver bullet" to solve all the issues. Thus, combining all $3 \mathrm{KSF}$ appears to be the most optimum solution to anticipate the issues, which suggests that an integration of the $3 \mathrm{KSF}$ s would be ideal for delivering a more effective and efficient FM to the asset's owners.

\section{The potential way forward: a proposed model}

The study found that the information is shared amongst various stakeholders in different formats. The proposed $3 \mathrm{KSF}$ s can make it easier to collect relevant information from different stakeholders and stored in a common platform to be utilised by different stakeholder simultaneously. However, the effectiveness of a particular KSF in addressing certain O\&M issues would vary depending on nature of the problem. Following a thorough analysis of the sources, emergence and impacts of issues occurred during the FM phase by studying the information flow between pre-completion and post completion phases of these projects, the study proposes an integration of the KSFs to effectively address O\&M issues occurring in the studied cases of commercial buildings.

The findings from the semi-structured interview revealed the OCC as an effective media to share and collaborate among stakeholder (respondents 6, 13, 16 and 17) and SLF as useful in ensuring a complete documentation which is vital for the FM team (respondents 17 and 18). BIM on the other hand has been perceived an effective way to collect, share, modify, update and store from the very beginning of the construction project to the very end (Lee and Akin, 2010 and respondents 7, 9, 17, 18) that will remove the cumbersome handing over of documentation (respondent 7, 11, 12, 15 and 18) and was deemed capable of improving the workflow and information transfer between project parties and streamlining the process of defects rectification (respondent 13, 14, 15, 17 and, 18). However, it was also acknowledge that implementing the KSFs such as BIM can typically be justified only in large and complex projects and/or where the (main) contractors are responsible for both the construction and O\&M of the buildings (respondents 2, 7, 12,16 and 18).

Many of its practitioners referred the built environment industry as a challenging industry with the overall performance of the industry declining, which manifested in the increase of adversarial behaviour among project stakeholders mainly due to poor documentation and inadequate data interoperability (Bishop et al., 2008). Australia is not an exception. All the participating interviewees asserted that a significant level of knowledge sharing gaps exists in Australian construction industries and one of the key reasons is the failure to integrate the 'silo' of information through an integrated model. Therefore, the study proposed an integrated knowledge sharing model where information shared between project life cycle phases are captured using and stored within the KSFs, i.e. OCC, SLF and BIM. Further analysis in this research revealed the need to integrate these KSFs into a single knowledge and information sharing database (refer to figure 5). It is acknowledged that the knowledge 
sharing practices are not a new concept and it has been practiced in the construction industries. However, it is expected that the proposed conceptual model can help removing the 'silos' of information and knowledge among various stakeholders as well as various stages in a project life-cycle by bringing in together OCC, SLF and BIM to develop an integrated knowledge sharing practice that will benefit all stakeholders, mainly the asset owners, building users and facilities management professionals.

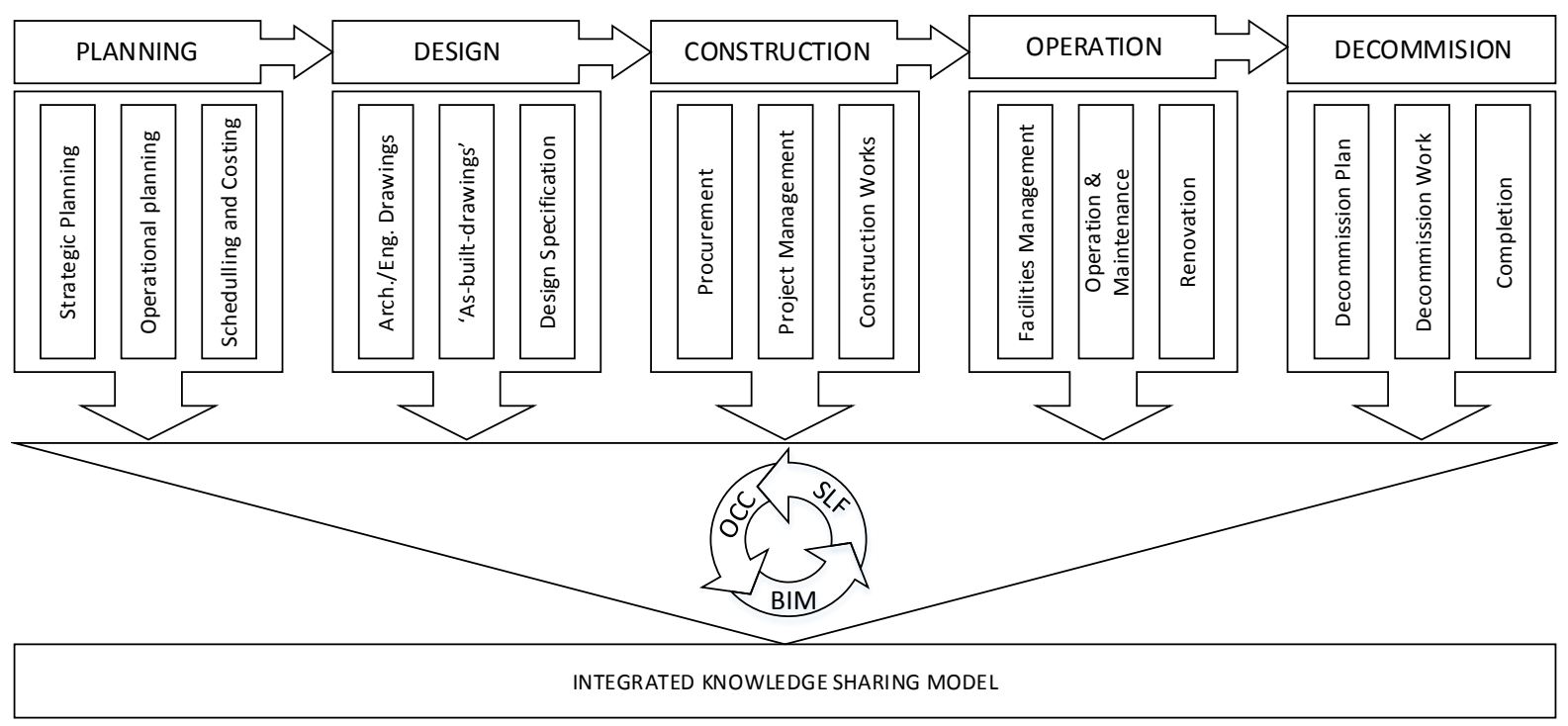

Figure 5: An integrated knowledge sharing model

\section{Conclusions}

Information has been regarded the lifeblood of operations and maintenance (O\&M) as O\&M typically requires an extensive amount of building information. The literature review conducted in this research has revealed that the information facilities managers received during project handover does not always match all the information required to effectively carry out activities within the O\&M phase (which was later verified and detailed in the studied cases of 3 commercial buildings). This has necessitated the formulation of this research to identify the information gap between handover and maintenance, and subsequently make recommendations aimed to bridge the information gap and improve practices in this field.

The study identified real gaps in information and knowledge transfer and sharing between various phases of construction project and facilities management phase. Through a thorough analysis of the 3 case study, tracking the sources, emergence and impacts of major issues faced during the FM phase, the potential of integrating the proposed $3 \mathrm{KSFs}$, namely OCC, SLF and BIM have been mapped to anticipate the issues in future projects. Whilst the detailed major issues identified in this research can be considered technical, further literature review and data analysis also unveiled the underpinning mind-set giving way to 'silos in knowledge and information' as an inherited characteristic from the construction industry. As the mapping analysis indicated an optimum way would be to integrate all 3 KSFs in anticipating the issues, their integration can also pave the way to change the silos mind set and aiming for the common goal, i.e. to provide an excellent facility. 
The main contributions of this research can be grouped into 3 major groups. Firstly, the methodology of tracking the sources, emergence and impact of major issues in a building project using the information flow diagram that can be used to analyse issues faced in other projects. Whilst the case studies are all based in the Western Australia, the tracking methodology can easily be implemented in any assets. Secondly, this research unlocked the potential of the proposed KSFs in anticipating the identified issues in future projects and FM operations. Whilst each of the KSF can be considered existing, the novel idea proposed here was to integrate them based on their capabilities to anticipate the issues. There are, however, various circumstances in different countries that may support or hamper the implementation and integration of the KSFs such as local regulations. The way each KSF is proposed to anticipate the issues in this paper is based on Western Australian (and the UK's due to similarities of regulations) circumstances. And thirdly, this integration was brought forward to enable the development of an integrated knowledge sharing model. The development of this conceptual model is aimed to change the silos mind-sets in the construction and facilities management industries. The conceptual model is aimed at a high level of abstraction and is not proposed as a "silver bullet" that can solve or anticipate facilities management issues. This research, for instance, can be extended to carry out the implementation of the integrated knowledge sharing model in real construction projects in order to refine the model in a longitudinal study or an action research. This is, however, considered further research and hence, beyond the scope of this paper.

\section{References}

Amaratunga, D., Baldry, D., Sarshar, M. and Rita Newton. (2002), "Quantitative and Qualitative Research in the Built Environment: Application of 'Mixed' Research Approach." Work Study 51 (1): 17-31.

Anumba, C. J., Catherine, B., and Malik M.A.K. (2002), “Organisational Structures to Support Concurrent Engineering in Construction", Industrial Management \& Data Systems 102 (5): 260-270.

Aoalsteinsson, G.O. (2014), "Feasibility Study on the Application of BIM Data for Facility Management", School of Science and Engineering, Reykjavik University, available at: http://skemman.is/is/stream/get/1946/19391/44666/1/GU\%C3\%90MUNDUR_\%C3\%93SKAR_A\%C3\%90 ALSTEINSSON-Feasability_study_of_application_of_BIM_data_for_facility_management.pdf (accessed 20 February 2016).

Asen, Y. (2012), "Building Information Modeling Based Integration and Visualization for Facilities Management." Master, Building, Civil and Environmental Engineering, Concordia University. http://spectrum.library.concordia.ca/974104/ (accessed 12 May 2016).

Atkin, B. and Adrian B. (2009), Total Facilities Management, Adrian Brooks, Wiley-Blackwell, Chichester, U.K.

Australian Constructors Association. (1999), “Relationship Contracting: Optimising Project Outcomes”, available at http://www.constructors.com.au/publications/rc_general/Relationship\%20Contracting\%20Optimising\% 20Project\%20Outcomes.pdf (accessed 12 February 2016).

Becerik-Gerber, B., Jazizadeh, F., Li, N., and Calis, G. (2011), “Application areas and data requirements for BIMenabled facilities management", Journal of construction engineering and management, 138(3), 431-442.

BIM Task Group, 2013. Government Soft Landings, BIM Task Group, available at http://www.bimtaskgroup.org/wp-content/uploads/2013/05/Government-Soft-Landings-Section-1Introduction.pdf (accessed 16 June 2016).

Bishop, D., Alan, F., Alison, F., Nick, J., Konstantinos, K., and Lorna, U. (2008), Constructing Learning: Adversarial and Collaborative Working in the British Construction Industry, available at: http://learningaswork.cf.ac.uk/outputs/Working_Paper_13.pdf (accessed 12 February 2016). 
Bordass, B. and Leaman, A. (2005), “Making feedback and post-occupancy evaluation routine 1: A portfolio of feedback techniques", Building Research \& Information, Vol. 33 No. 4, pp. 347-352

BSRIA (2016), Soft Landings, published by the Building Services Research and Information Association, available at https://www.bsria.co.uk/services/design/soft-landings/ (accessed 17 September 2016).

Coates, P, Arayici Y., Koskela, K., Kagioglou, M. Usher, C. and O'Reilly, K. (2010), "The Key Performance Indicators of the BIM Implementation Process." In The International Conference on Computing in Civil and Building Engineering, Nothingham, UK.Nottingham University Press. http://usir.salford.ac.uk/9551/ (accessed 12 May 2016).

Collinge, W.H., Chris, H., Kecheng, L. and Yinshan, T. (2009), “Improving Information Sharing across Construction Stakeholders: An Organizational Semiotics Approach", CIB Joint International Symposium: Construction facing worldwide challenges, Dubrovnik, Croatia.

Dainty, A., Moore, D., and Murray, M. (2007), Communication in construction: Theory and practice, Routledge, Abingdon, Oxon.

DTF (2005), Maintenance Policy, edited by Department of Treasury and Finance, Western Australia.

East, W., Nicholas, N., and Thomas, L. (2013), Facility Management Handover Model View, Journal of Computing in Civil Engineering 27 (1): 61-67.

Eastman, C., Paul, T., Rafael, S., and Kathleen, L. (2011), BIM Handbook: A Guide to Building Information Modelling for Owners, Managers, Designers, Engineers and Contractors, in Building Information Modelling Handbook, 2nd ed, Wiley, Hoboken, NJ.

Elmualim, A., and Pelumi-Johnson, A. (2009), Application of computer-aided facilities management (CAFM) for intelligent buildings operation, Facilities, 27(11/12), 421-428.

Engineers Australia (2005), Getting It Right the First Time: A Plan to Reverse Declining Standards in Project Design Documentation within the Building and Construction Industry, Brisbane, Australia.

Fallon, K.K., and Palmer, M.E. (2006), Capital Facilities Information Handover Guide, Part 1, edited by U.S. Department of Commerce, National Institute of Standards and Technology.

Flores-Colen, I., de Brito, J., and Freitas, V. (2010), Discussion of Criteria for Prioritization of Predictive Maintenance of Building Façades: Survey of 30 Experts, Journal of Performance of Constructed Facilities 24 (4): 337-344.

Gallaher, M.P., Alan, C., O'Connor, J.L. Dettbarn, J., and Linda T.G. (2004), Cost Analysis of Inadequate Interoperability in the U.S. Capital Facilities Industry, available at: http://fire.nist.gov/bfrlpubs/build04/PDF/b04022.pdf (accessed 12 February 2016).

Guion, L.A., David C.D., and Debra, M. (2011), Triangulation: Establishing the Validity of Qualitative Studies, available at: http://edis.ifas.ufl.edu/pdffiles/FY/FY39400.pdf (accessed 12 February 2016).

Hahn, J., and Subramani, M. R. (2000), "A framework of knowledge management systems: issues and challenges for theory and practice." Proceedings of the twenty first international conference on Information systems. Association for Information Systems, 2000.

Huczynski, A. and Buchanan, D. (2001), Organizational Behaviour: An Introductory Text (4th Edn), Essex, Prentice Hall, NJ.

Kvale, S. (2007), Planning an Interview Study: Doing Interviews, Sage Publications, California.

Lee, S. and Akin, O. (2010), Augmented Reality-Based Computational Fieldwork Support for Equipment Operations and Maintenance, Automation in Construction 20 (2011): 338-352.

Lewis-Beck, M.S., Alan, B. and Tim, F.L. (2004), The Sage Encyclopedia of Social Science Research Methods, Encyclopedia of Social Science Research Methods, Thousand Oaks, California.

Loebbecke, C., Van, F., Paul, C. and Powell, P., (2016), Managing inter-organizational knowledge sharing, The Journal of Strategic Information Systems, 25(1), pp.4-14. 
Melbourne City Council, (2012), “Facilities Management: Good Practice Guide”, Melbourne, VIC, available at https://www.melbourne.vic.gov.au/SiteCollectionDocuments/good-practice-guide-facilitiesmanagement.pdf (accessed 13 October, 2015).

Morton, J. (2011), BIM - the Intelligent Choice for O\&M, Buildings, 105 (8): 32-36.

Motawa, I. and Almarshad, A. (2013), "A knowledge-based BIM system for building maintenance", Automation in Construction 29: 173-182.

Olofsson, T., Lee, G., \& Eastman, C. (2008), “Editorial-Case studies of BIM in use”, IT in Construction, Special Issue Case studies of BIM use, 13, 244-245.

Pathirage, C., Haigh, R., Amaratunga, D., and Baldry, D. (2008), Knowledge management practices in facilities organisations: a case study, Journal of Facilities Management, 6(1), 5-22.

PCA (2014), Perth Office Vacancies Rise on Weak Demand, Property Council of Australia, available at: http://www.propertyoz.com.au/Article/NewsDetail.aspx?p=16\&id=8916 (accessed 13 October, 2015).

Pothier, D., Monteiro, P., Mooktiar, M. and Shaw, A. (2005), Pilot study to show the loss of important data in nursing handover, British Journal of Nursing, 14(20), pp.1090-1102.

Prior, Josephine J., and Francoise Szigeti. 2003. Why All the Fuss About Performance Based Building. International Council for Research and Innovation in Building and Construction-PeBBu Thematic Network

Richards, L., and Morse, J. M. (2007), Readme First for a User's Guide to Qualitative Methods, 2nd ed. Sage Publications, California.

Rubenstein-Montano, B., Liebowitz, J., Buchwalter, J., McCaw, D. Newman, B. and Rebeck, K. (2001), "A systems thinking framework for knowledge management", Decision Support Systems 31(1): 5-16.

Sabol, L. (2008), Building Information Modeling \& Facility Management, IFMA World Workplace, Design + Construction Strategies, Washington, DC.

Sinclair, D. (2013), RIBA Plan of Work 2013 Overview, available at:

http://www.architecture.com/Files/RIBAProfessionalServices/Practice/RIBAPlanofWork2013Overview.p df (accessed 13 February, 2016).

Skripac, B.P., and Hira, S. (2013), The Next Step, Health Facilities Management 26 (8): 21-25.

Strauss, A. and Juliet, C. (2015), Basics of Qualitative Research - Grounded Theory Procedures and Techniques, $4^{\text {th }}$ Edition, Sage Publications, California.

Su, Y.C., Lee, Y.C. and Lin, Y. C. (2011), Enhancing Maintenance Management Using Building Information Modeling in Facilities Management, 28th ISARC, Seoul, Korea.

Succar, B. (2009), Building information modelling framework: A research and delivery foundation for industry stakeholders. Automation in construction, 18(3), 357-375.

Sutrisna, M. and Barrett, P. (2007), "Applying rich picture diagrams to model case studies of construction projects." Engineering, Construction and Architectural Management 14(2): 164-179.

Sutrisna, M. and W. Setiawan (2016), The Application of Grounded Theory Methodology in Built Environment Research. Research Methodology in the Built Environment: A Selection of Case Studies. V. Ahmed, A. Opoku and Z. Aziz. Oxford, Taylor and Francis.

Teicholz, Eric. (2001), Computer-aided facilities management and the internet, Emerging Information Technologies for Facilities Owners: Research and Practical Applications, Symposium Proceedings, available at http://www.nap.edu/read/10217/chapter/3 (accessed 12 May 2016).

Usable Buildings Trust, (2014), The Soft Landings Framework for Better Briefing, Design, Handover and Building Performance in-Use, BSRIA, available at: https://www.bsria.co.uk/services/design/soft-landings/ (accessed 13 February, 2016).

UTAS (2011), Property Service: Project Handover Guidelines, available at: http://www.utas.edu.au/_data/assets/pdf_file/0009/159507/Project-Handover-Guidelines.pdf (accessed 13 February, 2016). 
Way, M. and Bordass, B. (2005), "Making feedback and post-occupancy evaluation routine 2: Soft landingsinvolving design and building teams in improving performance." Building Research $\mathcal{E}$ Information 33(4): 353-360.

Way, M. and Bordass, W., (2009), The Soft Landings Framework: for better briefing, design, handover and building performance in-use. BSRIA.

Zeng, S. X., Lou, G. X., \& Tam, V. W. (2007), Managing information flows for quality improvement of projects, Measuring business excellence, 11(3), 30-40. 